\title{
USING SATELLITE REMOTE SENSING DATA TO SUPPORT WATER MANAGEMENT IN ARID AND SIMI-ARID AREA
}

\author{
O. M. Mohamed ${ }^{1}$, A. M. El-Gindy ${ }^{2}$; \\ Y. A. Arafa ${ }^{2}$ and M. S. Abd-Elwahed ${ }^{3}$ \\ ABSTRACT
}

Remote sensing techniques are becoming powerful tools for efficient management of irrigation systems in large irrigated areas. Crop water requirements are usually denoted by the actual crop evapotranspiration. Estimation of crop evapotranspiration (ET $\left.T_{c}\right)$ using remote sensing data is needed for water management in arid and semiarid regions. This study attempts to link the satellite image data to estimate the temporal crop evapotranspiration using Landsat Thematic Mapper TM and Système Pour l'Observation de la Terre (SPOT4) satellite images. The satellite images geometrically and radio metrically corrected and were used to drive the Normalized Difference Vegetation Index NDVI. This research study showed that how remote sensing data can be integrated in FAO dual approach for mapping water use (ETc) of wheat crop in semi-arid region. The method consists of linking the main crop biophysical parameters (basal crop coefficient, cover fraction) to the (NDVI).

Keywords: Remote sensing, ET, Water management, vegetation indices.

\section{INTRODUCTION}

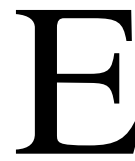
gypt is categorized among the regions that face high water shortages. This is mostly due to both the insistent drought and the increase of water demands especially in agricultural sector.

The most common and practical approach widely used for estimating crop water requirement, and the operational monitoring of soil-plant water balance is the estimation of ETc by combination of a reference evapotranspiration $\left(\mathrm{ET}_{\mathrm{o}}\right)$ and crop coefficients (Salah et al, 2010).

1 Post-Graduate student Agric. Engneering.Dept., Faculty of Agric., Ain Shams Univ.

2 Agric. Engneering.Dept., Faculty of Agric., Ain Shams Univ.

3 Soil Sc. Dept., Faculty of Agric., Ain Shams Univ. 
According to Dingman (2002), evapotranspiration (ET) can be defined as a collective term for all the processes by which water at or near the land surface becomes atmospheric water vapor. The word is composed of the term evaporation, referring to water vapor coming from liquid water such as rivers, lakes, bare soil and vegetation surfaces, and the term transpiration, referring to the water vapor originating from within the leaves of plants. Evaporation and transpiration are different processes governed by different rules, but since the earth's surface is often covered by a mixture of open water, soil and vegetation, it can be difficult to distinguish between the two fluxes, and for operational purposes they are often treated as one. Direct measurement of ET is practically impossible, and therefore there exists a long list of methods to indirectly estimate ET.

Estimates of land surface evapotranspiration (ET) using remote sensing data are essential in effective planning of irrigation water use in arid and semi-arid regions.

Remote sensing data could provide an indirect estimation of crop coefficient or basal crop coefficients. Certainly, some authors have shown correlation between the seasonal patterns of vegetation indices and transpiration over annual crops (Hunsaker, et al, 2003; and ErRaki et al, 2007). Therefore, Kc can be estimated from spectral vegetation indices, such as normalized difference vegetation index (NDVI) (Tucker et al. 1991) and the soil-adjusted vegetation index (SAVI) (Huete, 1988), they have been tested to predict crop coefficients at field and regional scales since both of them are related to leaf area index and fractional ground cover (Salah et al, 2010). In this context, establishing a relationship between crop coefficient and spectral vegetation indices is an enduring research subject.

The objective of this study is to test the ability of remote sensing techniques to monitor the temporal crop evapotranspiration in the study area from spectral vegetation index, NDVI derived from the satellite images. 


\section{The study area}

The region of interest is an irrigated area located in El-Noubaria reclamation zone - El-Bustan Extension, Beheira Governorate. (Figure1).

Land elevation of the project areas ranges between 5 meters above sea level (ASL) in the east and 80 meters (ASL) in the west, with slope percentage range between 1 to $5 \%$ from west to east. The dominant elevation is 27 meters east of the Alexandria-Cairo desert road and 40 meters in the northwestern part of the road. In general the project areas are flat to almost flat. The climate is of arid to semi-arid type.

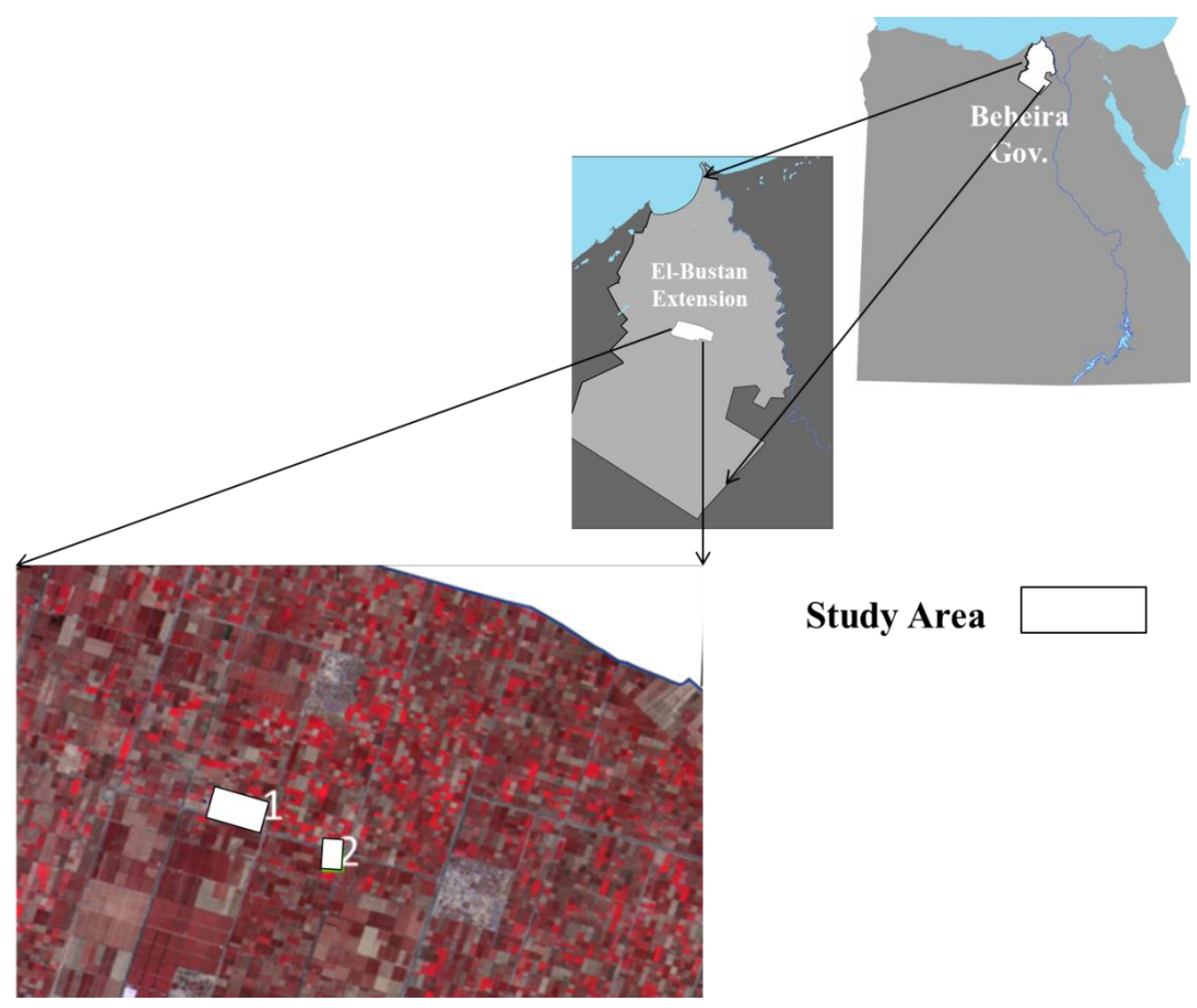

Figure 1: Location of the study sites

The study area is irrigated from the Noubaria canal and its network of subsidiary canals. The Noubaria canal itself was constructed in the 1960s and extends from a point on the Rosetta branch of the Nile, about $40 \mathrm{~km}$ 
north of Cairo. Two branch canals, the Nasr canal and the El Bustan canal, supply water to the higher parts of the new lands by pumping.

\section{MATERIALS AND METHODS}

Two farms cultivated with wheat were chosen as study sites; the first one is $80000 \mathrm{~m}^{2}$ area and the other one is $40000 \mathrm{~m}^{2}$.

The reference evapotranspiration $\left(\mathrm{ET}_{\mathrm{o}}\right)$ and the crop coefficient $\left(\mathrm{K}_{\mathrm{c}}\right)$ were calculated using the field data acquired for three different growth stages; developing growth stage, middle season growth stage and late growth stage and the climatic date that were recorded at El Bustan Weather Station. The plant height data and the tabled values of $\left(\mathrm{K}_{\mathrm{c}}\right)$, in addition to meteorological data were used in these calculations.

The tabulated values of $\mathrm{Kc}$ were modified to the real values of crop coefficient using Equation.1.

$K_{\text {cstage }(n)}=K_{c \text { stage }(n)(T a b)}+\left[0.04\left(u_{2}-2\right)-0.004\left(R H_{\min }-45\right)\right]\left(\frac{h}{3}\right)^{0.3}$ Eq.1

Where

$\boldsymbol{K}_{\text {cstage }(n)(T a b) \text { for }} \boldsymbol{K}_{\boldsymbol{c} \text { stage( }(\boldsymbol{n})}$ tabulated (Allen et al, 1998)

$u_{2} \quad$ value for daily wind speed at $2 \mathrm{~m}$ height over grass during the growth stage $\left[\mathrm{m} \mathrm{s}^{-1}\right]$

$R H_{\min } \quad$ value for daily minimum relative humidity during the growth stage [\%]

h. Plant height for each growth stage $[\mathrm{m}](0.1 \mathrm{~m}<\mathrm{h}<10 \mathrm{~m})$.

\section{Remote sensing and GIS}

In this study, we used a model that was developed by Allen et al (1998). This model defines the relationship between the crop evapotranspiration under standard conditions $\left(\mathrm{ET}_{\mathrm{c}}\right)$ and reference evapotranspiration $\left(\mathrm{ET}_{0}\right)$ by separating crop coefficient $\left(K_{c}\right)$ into basal crop coefficient $\left(K_{c b}\right)$ and soil evaporation coefficient $\left(K_{e}\right)$ (equation 2$)$ :

$$
\mathrm{ET}_{\mathrm{c}}=\left(K_{c b}+K_{e}\right) \mathrm{ET} 0 \quad \mathbf{E q . 2}
$$


In order to integrate the remote sensing data into this model, both $\mathrm{K}_{c b}$ and $\mathrm{K}_{e}$ in equation 1 were derived from NDVI. The crop coefficient was obtained from satellite imagery directly from NDVI using equations 3 and 4 based on the relationship between NDVI and the basal crop coefficient according to Bausch and Neale (1987). The operational procedure to estimate $\mathrm{Kcb}$ from satellite imagery is based on the relationship between NDVI and basal crop coefficient.

$$
\begin{array}{cc}
K_{c b}=1.07\left[1-\left(\frac{N D V I_{\text {max }}-N D V I}{N D V I_{\text {max }}-N D V I_{\text {min }}}\right)^{\frac{0.84}{0.54}}\right] & \text { Eq.3 } \\
\mathrm{K}_{\mathrm{e}}=0.25\left(1-\mathrm{f}_{\mathrm{c}}\right) & \mathbf{E q . 4}
\end{array}
$$

Where $\mathrm{NDVI}_{\text {min }}$ and $\mathrm{NDVI}_{\max }$ are the minimum and the maximum values of NDVI, respectively. $f_{c}$ is the vegetation fraction cover given by

Equation 5 according to Er-Raki et al (2007).

$$
\mathrm{F}_{\mathrm{c}}=1.18\left(\mathrm{NDVI}-N D V \mathrm{I}_{\min }\right)
$$

Eq.5

Thus, crop coefficients derived from spectral measurements $(\mathrm{Kc})$ are independent of the time parameters, day of planting and effective cover, and represent a real-time crop coefficient. The use of spectral crop coefficients facilitates irrigation scheduling on a field-to-field basis over a large region if the fields can be observed spectrally, because planting and assumed effective cover dates are not required. When the crop is well developed and completely covers the soil $(\mathrm{fc}=1)$.

The Landsat and SPOT-4 satellite data were employed in this study. The data is acquired for three different growth stages; early stage (December) using Landsate ETM, middle season growth stage (February) and late growth stage (April) using SPOT-4. The original data were geometrically corrected and geographically referenced to a map base, co-registered corresponding to the WGS 84 spheroid and the UTM zone 36 Datum by a first-order polynomial transformation to generate images in a UTM projection. The scenes were later subset to the study area of interest. The images then used to calculate the Normalized Difference Vegetation Index (NDVI)

NDVI was calculated from three scenes using the following Equation (equation 6). The principle behind NDVI is that the red band is where 
chlorophyll causes considerable absorption of incoming sunlight, while the near infrared (NIR) band is where a plant's spongymesophyll leaf structure creates considerable reflectance (Truker et al, 1991). As a result, NDVI values vary according to the vegetation status.

$$
\mathrm{NDVI}=\frac{\rho_{\mathrm{NIR}}-\rho_{\text {red }}}{\rho_{\mathrm{NIR}}+\rho_{\text {red }}} \quad \text { Eq.6 }
$$

Where

$\rho_{\text {NIR }} \quad$ Near infrared band reflectance.

$\rho_{\text {red }} \quad$ Red band reflectance.

\section{RESULTS AND DISCUSSION}

The metrological data collected from El-Bustan meteorological station were used to calculate the reference evapotranspiration (ETo) using (CROPWAT 8.0). The metrological data for the study area, obtained from El-Bustan metrological station, and the ETo values are shown in table (1).

The highest value of the ETo was in February compared to the early and late growing stages in December and April respectively.

On the other hand, figure (2) shows the NDVI images for the two study

Table 1: The metrological data for the study area and the calculated ETo values.

\begin{tabular}{|c|c|c|c|c|c|}
\hline \multirow[t]{2}{*}{ Month } & $\begin{array}{c}\text { Min. } \\
\text { Temperature }\end{array}$ & $\begin{array}{c}\text { Max. } \\
\text { Temperature }\end{array}$ & $\begin{array}{l}\text { Relative } \\
\text { Humidity }\end{array}$ & $\begin{array}{c}\text { Wind } \\
\text { Speed }\end{array}$ & ETo \\
\hline & ${ }^{\circ} \mathrm{C}$ & ${ }^{\circ} \mathrm{C}$ & $\%$ & km/day & $\mathrm{mm} / \mathrm{day}$ \\
\hline Dec. & 7.8 & 19.7 & 77 & 502 & 2.4 \\
\hline Feb. & 12.7 & 29.1 & 84 & 220 & 4.03 \\
\hline Apr. & 11.6 & 25.8 & 80 & 199 & 3.6 \\
\hline
\end{tabular}

sites as well as the Min. and Max. Vegetation Index values for each growth stage. The NDVI calculated from satellite images shows that the 
NDVI values of the middle season growth stage were higher than those of both of the developing and the late season growth stages.

A comparison between ETc calculated using NDVI satellite images with the measured ET over the two fields of wheat is shown in figure (3).

The comparison in this figure denotes that the model under investigation that developed by Allen et al (1998) fittingly employs the satellite remote sensing data to simulate ETc values for wheat crop fields. The coefficient of determination $\left(\mathrm{R}^{2}\right)$ is around 0.73 .

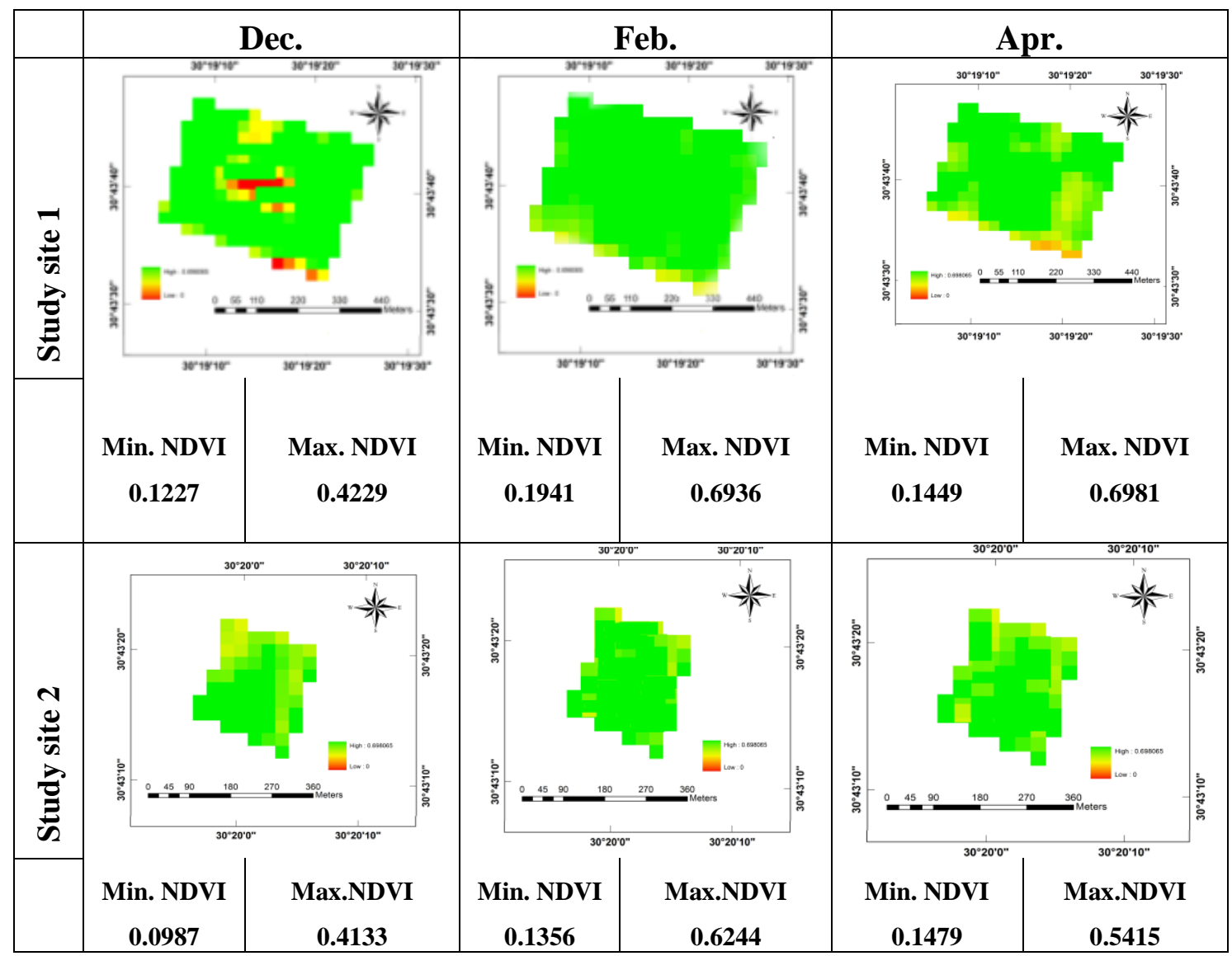

Figure 2:The NDVI images for the two study sites in three different growth periods. 


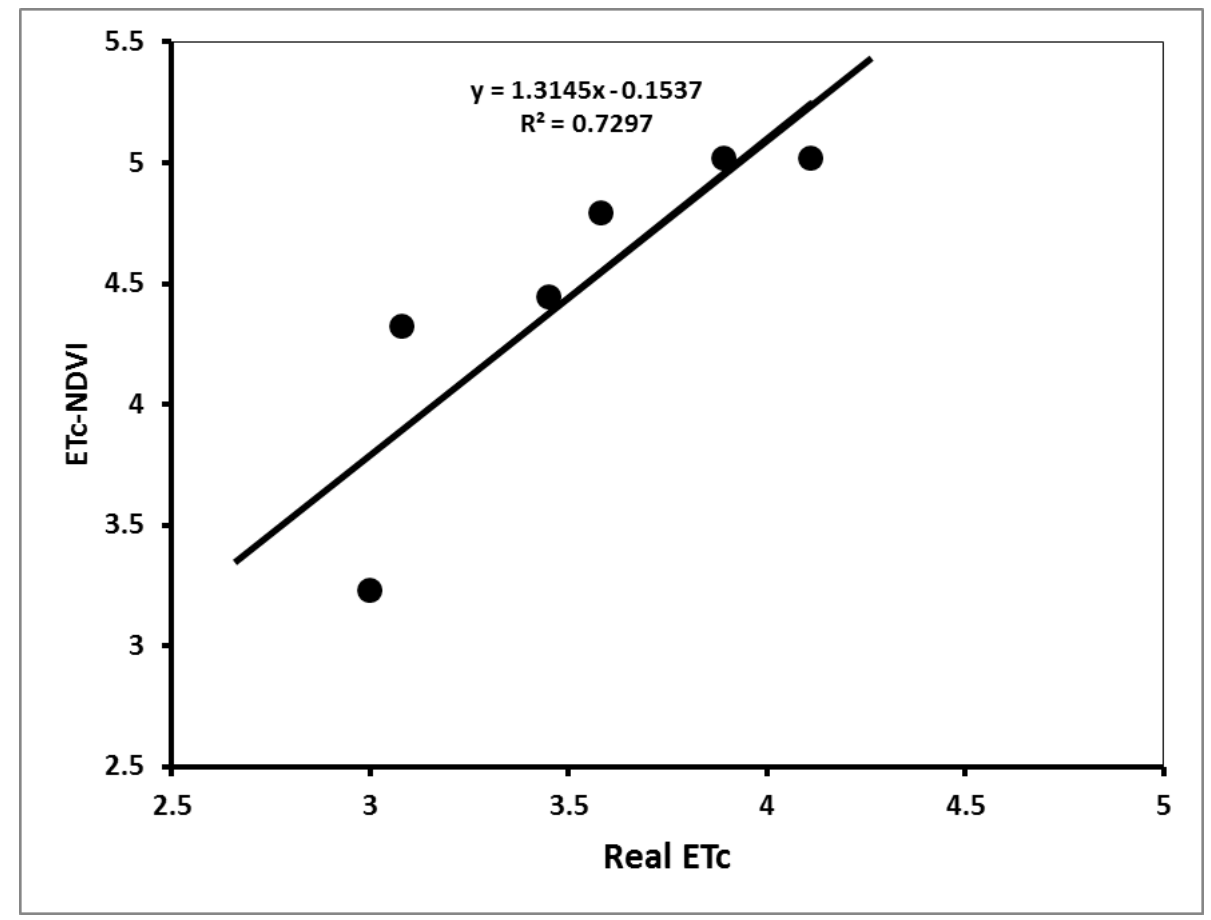

Figure 3: relationship between Real ETc and ETc calculated from NDVI images.

The results of this study showed that remote sensing data can be integrated with the main crop biophysical parameters (basal crop coefficient, cover fraction) for mapping water use (ETc) of wheat crop in semi-arid region.

The analysis results show that estimating the crop coefficient $\mathrm{Kc}$ and crop water requirements using remote sensing data is substantial. The crop evapotranspiration was higher in the middle season growth stage than the developing and the late season growth stage. These results agreed with those of Salah and Duchemin (2010) who mentioned that remote sensing estimates of $\mathrm{ET}_{\mathrm{c}}$ compare very satisfactorily with ground measurements, since the soil evaporation and plant water stress are negligible. The results also dealt with those of Gauravet. al. (2010) who mentioned thatwheat water requirement was higher in the vegetative and mid-season stage and decreased towards the maturity stage. Instead, Penman-Monteith is proven as one of the best empirical models, but it 
requires detailedfield climatic data measurements, which is difficult and costly for some of the developing countries. The tabulated FAO-56 crop coefficient values seem to be not applicable in some parts of the world giving a higher estimation of crop water need.

\section{REFFERANCES}

Allen, R.G.; Pereira, L.S.; Raes, D.; Smith, M. 1998.Crop Evapotranspiration: Guidelines for Computing Crop Water Requirements; FAO Irrigation and Drainage Paper 56; FAO: Rome, Italy; p. 300

Bausch, W.C. and Neale, C.M.U. 1987. Crop Coefficients Derived from Reflected Canopy. Transactions of the ASAE, 30(3):703-709.

Dingman, S.L., 2002: Physical Hydrology, 2nd Ed.: Upper Saddle River, New Jersey.

Prentice Hall.Er-Raki, S.; Chehbouni, A.; Guemouria, N.; Duchemin, B.; Ezzahar, J. and Hadria, R. 2007.Combining FAO-56 model and ground-based remote sensing to estimate water consumptions of wheat crops in a semi-arid region.Agr. Water Manage. 87, 41-54.

Gaurav. P. P. and Gupta, J. N. (2010). Crop and irrigation water requirement estimation by remote sensing and GIS: a case study of Karnal district, Haryana, India. International Journal of Engineering and Technology Vol.2 (4), 207-211.

Huete, A.R. 1988, A soil-adjusted vegetation index (SAVI). Remote Sens. of Environ. 25 (3), 295-309.

Hunsaker, D.J.; Pinter, P.J., Jr.; Barnes, E.M.; and Kimball, B.A. 2003.Estimating cotton evapotranspiration and crop coefficients with a multispectral vegetation index.Irrig.Sci, 22, 95-104.

Salah E., Chehbouni A. and Duchemin B. 2010.Combining Satellite Remote Sensing Data with the FAO-56 Dual Approach for Water Use Mapping In Irrigated Wheat Fields of a Semi-Arid Region. Remote Sens. 2, 375-387

Tucker, C.J, Dregne, H.E, and Newcomb, W.W. (1991) Expansion and contraction of the Sahara Desert from 1980 to 1990. Science, 253: pp299- 301. 


\section{الملخص العربيى}

\section{توظيف بيانات الأستشعار عن بعد بالأقمار الصناعية في إدارة المياه في

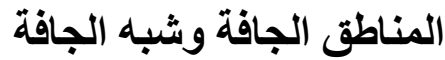

أسامة مبارك محمد '، عبد الغنى الجندي ‘، ياسرعزت هاشمَّ و محمد سيف الدين عبدالواحد

أصبحت تقنيات الاستشعار عن بعد من التقنيات المؤثرة في الإدارة الفعالة لنظم الري في ذاتي

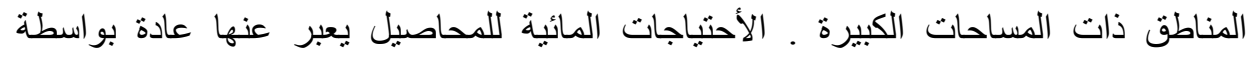
البخرنتح الفحلي للمصصول. و يلاحظ في المناطق الجافة وشبة الجافة الحاجة الى تقدير

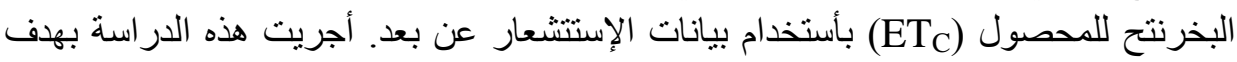
أستخدام البيانات المتحصل عليها من صور الأقمار الصناعية لتقدير البخرنتح للمحصول باستخدام صور القمر الصناعي TM والقمر الصناعي SPOT4 ـ تم تصحيح الصور الفضائية هندسيا و إشعاعيا و أستخدمت لحساب NDVI. و أظهرت هذه الدر اسة البحثية إمكانية أستخدام

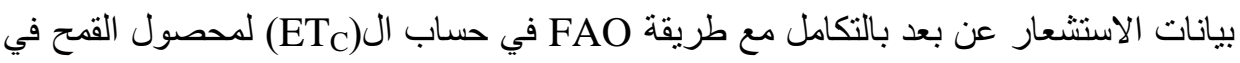
منطقة شبه جافة. تعتمد هذة الطريقة بصفة أساسية على ربط بيانات المحصول بلى البيوفيزيائية

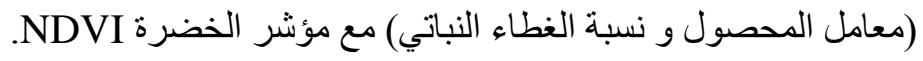

